Article

\title{
Adapting Free, Prior, and Informed Consent (FPIC) to Local Contexts in REDD+: Lessons from Three Experiments in Vietnam
}

Thuy Thu Pham ${ }^{1, *}$, Jean-Christophe Castella ${ }^{2}$, Guillaume Lestrelin ${ }^{2}$, Ole Mertz ${ }^{3}$, Dung Ngoc Le ${ }^{1}$, Moira Moeliono ${ }^{4}$, Tan Quang Nguyen ${ }^{5}$, Hien Thi $\mathbf{V u}^{6}$ and

Tien Dinh Nguyen ${ }^{7}$

1 Center for International Forestry Research, 17A Nguyen Khang Street, Cau Giay District, Hanoi 100000, Vietnam; E-Mail: t.pham@cgiar.org

2 Institute of Research for Development (IRD), Le Sextant, bd de Dunkerque, CS 90009, Marseille 13572, France; E-Mails: j.castella@ird.fr (J.-C.C.); g.lestrelin@gmail.com (G.L.)

3 Department of Geosciences and Natural Resource Management, University of Copenhagen, Øster Voldgade 10, DK-1350 Copenhagen, Denmark; E-Mail: om@ign.ku.dk

4 Center for International Forestry Research, Headquarters, Jalan CIFOR, Situ Gede, Bogor 16115, Indonesia; E-Mail: M.Moeliono@cgiar.org

5 The Center for People and Forests, Floor 3, A5B Building, Giang Vo 2, Tran Huy Lieu Street, Ba Dinh District, Hanoi 100000, Vietnam; E-Mail: tan@recoftc.org

6 The Centre of Research and Development in Upland Areas, Room 801, Cau Giay Agriculture Bank Block, Lane 106, Alley 106/10, Hoang Quoc Viet Street, Hanoi 100000, Vietnam;

E-Mail: tranvuhientk@yahoo.com

7 Center for Agricultural Research and Ecological Studies, Hanoi University of Agriculture, Trau Quy, Gia Lam District, Hanoi 10000, Vietnam; E-Mail: nguyentiencares@gmail.com

* Author to whom correspondence should be addressed; E-Mail: t.pham@cgiar.org; Tel.: +84-437-834645 (ext. 31-32); Fax: +84-437-834645.

Academic Editor: Eric J. Jokela

Received: 13 March 2015 / Accepted: 3 July 2015 / Published: 15 July 2015 


\begin{abstract}
Free, prior, and informed consent (FPIC) is a means of ensuring that people's rights are respected when reducing emissions from deforestation and forest degradation, and enhancing forest carbon stocks (REDD+) projects are established in developing countries. This paper examines how FPIC has been applied in three projects in Vietnam and highlights two key lessons learnt. First, as human rights and democracy are seen as politically sensitive issues in Vietnam, FPIC is likely to be more accepted by the government if it is built upon the national legal framework on citizen rights. Applying FPIC in this context can ensure that both government and citizen's interests are achieved within the permitted political space. Second, FPIC activities should be seen as a learning process and designed based on local needs and preferences, with accountability of facilitators, two-way and multiple communication strategies, flexibility, and collective action in mind.
\end{abstract}

Keywords: citizen rights; participation; empowerment; FPIC; Vietnam; REDD+

\title{
1. Introduction
}

Human rights and rights-based approaches have increasingly influenced international climate change debates and decision-making [1,2] and more specifically have been applied to the still negotiated international mechanism aiming at reducing emissions from deforestation and forest degradation and enhancing forest carbon stocks (REDD+) in developing countries. REDD+, to a large degree, depends on the willingness of local communities to engage in forest protection. It is thereby assumed that providing secure rights and control over the resources to local communities might lead to more effective implementation [3]. On the other hand, some see REDD+ as another attempt to take away control over resources and could lead to recentralization of forest governance, exclusion of local people from decision-making, and displacement from forest land held by indigenous groups who are denied access to traditional use of natural resources [4-6]. Safeguards, which are mechanisms to mitigate risks and potential negative impacts of REDD+, therefore need to be in place [7].

A rights-based approach can therefore be useful to provide "benchmarks of acceptable outcomes based on widely agreed principles and legal structure" [8] (p. 23). Article 15 of the Convention on Biological Diversity states: "Access to genetic resources shall be subject to prior informed consent of the Contracting Party providing such resources, unless otherwise determined by that Party". "Article 10 of the United Nations Declaration on the Rights of Indigenous Peoples (UNDRIP) also states that indigenous peoples shall not be forcibly removed from their lands or territories. No relocation shall take place without the free, prior, and informed consent of the indigenous peoples concerned and after agreement on just and fair compensation and, where possible, with the option of return.

Translating the concept from the international to the national policy arena, however, is highly complex [9], as it must be adapted to diverse sociopolitical context. As interest in REDD+ grows so do concerns about how it will affect rural communities in general and indigenous people in particular [10-12]. 
Under the United Nations Framework Convention on Climate Change (UNFCCC), parties to the Convention have agreed to a set of seven safeguards (UNFCCC Decision 1/CP.16) to be promoted and supported during REDD+ implementation, known as the Cancun safeguards. Four of these seven UNFCCC safeguards are related to social safeguards and three of them are: (i) "Transparent and effective national forest governance structures, taking into account national legislation and sovereignty"; (ii) "Respect for the knowledge and rights of indigenous peoples and members of local communities, by taking into account relevant international obligations, national circumstances and laws, and noting that the United Nations General Assembly has adopted the United Nations Declaration on the Rights of Indigenous Peoples"; and (iii) "The full and effective participation of relevant stakeholders, in particular indigenous peoples and local communities."

Although the term "FPIC" (Free Prior Inform Consent) is not explicitly referred to in the Cancun Agreements or in the appendix on REDD + safeguards, FPIC is addressed indirectly because the text notes that the General Assembly has adopted UNDRIP and is particularly grounded in the second paragraph of the safeguards that calls for: "The full and effective participation of relevant stakeholders, in particular indigenous peoples and local communities.".

FPIC is not new and has been previously applied in development, resource extraction, oil and gas exploitation, and other investment projects within territories of indigenous peoples [13]. Free means that consent is given freely and voluntarily, with no coercion, manipulation, or intimidation and following a process directed by the community, respecting the time requirements of indigenous consultation/consensus processes. Prior means that consent is to be sought in advance of any activities, at the early stages of development. In other words, the process of FPIC should be initiated sufficiently in advance of commencement or authorization of activities, taking into account indigenous people's own decision-making processes, in phases of assessment, planning, implementation, monitoring, evaluation, and closure of a project. Informed means that communities have been provided with complete information and understand the potential impact. Although there is no functional clarity about what constitutes "consent" [14], in general "consent" is understood as collective decision-making [15,16].

Yet, the concept of FPIC itself is still new in the REDD+ arena [17]. No definition is universally accepted [18] and there is often a gap between international norms and actual practice in different countries [13]. Furthermore, there is so far no common understanding on how to integrate all parts of FPIC: the elements of free, prior, and informed consent; the links between processes and outcomes; and the requirement that FPIC is employed at certain points in time during a REDD+ activity [19,20]. No unified method is available. FPIC is interpreted by the UN-REDD program (hereafter referred to as UN-REDD), as "the right of indigenous people to give or withhold their (indigenous people) free, prior, and informed consent to actions by others, that affect their land, territories, and natural resources" [15,21]. FPIC is also interpreted by many international scholars as the rights of indigenous people to exercise their right of self-determination under international human rights law instruments such as the International Covenant on Civil and Political Rights [18,22,23]. Any REDD+ initiatives are thus required "to ensure that indigenous peoples are not coerced or intimidated, that their consent is sought and freely given prior to the authorization or start of any activities, that they have full information about the scope and impacts of any proposed development, and that ultimately their choices to give or withhold consent are respected" [24]. UN-REDD also developed the FPIC guidelines to be used by partner countries and applied during national-level activities [25]. The guidelines outline FPIC criteria 
and propose a step-wise approach detailing what is required from partner countries to meet their extant commitments under a number of international agreements, including ILO Convention 169, UNDRIP, and UNCERD [15]. The guidelines also distinguish consent from mere consultation, specifying that FPIC is meant to enable communities to participate in decision-making processes and withhold their consent [15].

While UN-REDD adopts a rights-based approach in FPIC implementation, the Forest Carbon Partnership Facility (FCPF) chooses a different approach. The Facility is subjected to the World Bank's operational policy on Indigenous Peoples (OP/BP 4.10) which requires that the development process fully respects the dignity, human rights, economies, and cultures of indigenous people, and if it cannot be avoided, adverse effects on indigenous people should be "minimized, mitigated, or compensated" [26]. The OP/BP 4.10 also requires that if the proposed projects affect people, the bank requires borrowers to engage in Free Prior Informed Consultation and to achieve the "broad community support" of the affected indigenous peoples before the bank will provide financial support. The fact that FPIC is only required in some circumstances by the FCPF might engender a chasm with the UN-REDD. Moreover, the FCPFs only require "consultation" with exchange of information and views rather than establishing procedural rights to participation and access to information and creating an enabling environment for participations as required by "consent" under the Cancun safeguards. Furthermore, different national and regional governments apply different principles, which are often further complicated by donor requirements, NGO perceptions, and local demands.

Although there is a host of FPIC experience from other forest and environmental governance arrangements that can provide lessons for REDD + [27], few resources are available to train practitioners on implementation of FPIC for REDD+ [18]. Despite the UN-REDD guidelines, applying FPIC is difficult due to (i) weak understanding of how FPIC is adopted in different political and social contexts and the institutional arrangements required for FPIC [28]; (ii) lack of experience, with relatively few initiatives undertaken so far [22]; (iii) the procedural norms of FPIC, which tend to yield unexpected and ambiguous results [29]; and (iv) subjective understanding of the terms and requirements of FPIC, influenced by both cultural interpretations and political interests [17]. Further systematic and critical empirical research, including comparative case studies looking at FPIC and FPIC-like regimes operating around the world, could offer some useful insights [28].

In its implementation, FPIC is often interpreted as "the establishment of conditions under which people exercise their fundamental right to negotiate the terms of externally imposed policies, programs, and activities that directly affect their livelihoods or wellbeing, and to give or withhold their consent to them" $[19,30]$ (p. 20). However, the extent to which people can exercise their rights and influence decision-making, and the ways in which messages are communicated in a country depend on the national political setting and the local context [31]. Therefore, understanding the political environment in which FPIC is operating is crucial. In addition, there will be a difference between whether the right to FPIC is simply the result of its acknowledgment of international laws and standards on REDD+ (such as those of the UN-REDD) or of it is part of existing domestic legal frameworks or included in legal reforms that states may carry out as part of the REDD-readiness process.

In practice, FPIC rarely lives up to its stated ideals [22] and is often at risk of being seen simply as procedural, that is, followed mechanically without any consideration of the local context [32]. Whether FPIC is merely a procedural guarantee or not has also received increasing attention by many scholars [33]. 
Ideally, FPIC should be treated as a long-term learning process [19] and the political, economic, and social context needs to be carefully analyzed and taken into account in the FPIC design process [13]. It is therefore important to learn from FPIC pilot studies that have been conducted in different contexts. Given that many countries are still at a very early stage of understanding what FPIC is and how it can be integrated into their national REDD+ strategies, it is timely for countries to share their experiences with one another in order to facilitate learning on FPIC [25].

In this paper, we use case studies from Vietnam to offer lessons and recommendations for putting FPIC principles into practice effectively and efficiently in a variety of social and economic settings. REDD+ is still in its early stages in Vietnam, and like many other countries in the world, most REDD+ activities are pilot projects that have been under preparation for several years, but have not yet reached a full stage of implementation with transfer of carbon. Therefore, we focus on lessons learned from implementing FPIC, with special attention to how information is conveyed in the initial phases of REDD+ pilot projects in Vietnam. Information is also a necessary premise for participation and is part of well-established national and international laws, for example Principle 10 of the Rio Declaration. Furthermore, participation is explicitly included in the UNFCCC safeguards for REDD+, as stated above. We also discuss the challenges faced by the government and project managers to implement effective FPIC and argue that FPIC is likely to be more successful and accepted by the government of Vietnam if it is built upon the national regulations framework on citizen rights. The next section provides a description of the political context of REDD+ and FPIC in Vietnam. We then describe the research methods in Section 3. This is followed in Section 4 by a presentation and discussion of the findings.

\section{The Political Context of FPIC in Vietnam}

FPIC is a politically sensitive issue in many countries, which are reluctant to recognize the collective right of indigenous peoples to self-determination out of fear that it could threaten state sovereignty and lead to an escalation in claims for independence by indigenous peoples $[20,28,34]$. There is, however, a difference between internal self-determination (indigenous people have the rights to choose their political allegiances, to influence the political order in which they live, and to preserve their cultural, ethnic, historical, or territorial identity) and external self-determination (indigenous people have the right to determine their future international status and liberate themselves from existing rules, or the creation of an independent state); FPIC refers to the first and not to the second [35,36]. Moreover, many states engaged in REDD+ implementation have also ratified global and regional human rights treaties [37] that require them to respect and take positive measures to fulfill rights and protect subjects within their jurisdiction against violations carried out by third parties [38]. The right to FPIC, therefore, is directly linked to a state's obligation to uphold indigenous people's rights in the pursuit of their political commitment to those international treaties [30].

In the context of Vietnam, FPIC components are interpreted as follows [39]: Free means that stakeholders, particularly the local people, are entitled to participate freely, without any force or pressure. Prior means stakeholders are informed and consulted before a proposed project or activity that may impact them is commenced and thus before they may raise their voice against the project. Informed: stakeholders are entitled to be clearly and adequately informed of any possible impact (positive, negative, risk) of a proposed project or activity that may impact them. Information provided to each 
stakeholder has to indicate the reasons, the nature, the limitations, the scope, the scale, and the schedule as well as the possibility to retreat from any proposed project or activity that has developed for a specific site that may be impacted economically, socially, culturally, and environmentally.

Vietnam ratified the International Covenant on Civil and Political Rights in 1982, and thereby recognized the rights of its ethnic minorities. The term "indigenous people" is not used in Vietnam as it is perceived as a product of colonialism. With the collapse of colonialism, the Vietnam state referred to indigenous people as "ethnic minorities," indicating their minority status against the Kinh majority [40,41]. Nevertheless, in 2007, Vietnam ratified the United Nations Declaration on the Rights of Indigenous Peoples (UNDRIP) and in 2009 became the first country to implement FPIC under the UN-REDD program.

Vietnam's recognition of the rights of citizens and human rights is guaranteed in its successive constitutions. The 1946 Constitution affirmed that citizens' freedom and democratic rights are guaranteed, including freedom of speech, the right to referendum, and the right to participate in state and political affairs. The 1960 Constitution extended the contents of citizens' rights, paying special attention to the rights of vulnerable groups and economic, social, and cultural rights. The 1980 Constitution reaffirmed the citizens' fundamental rights and made the state responsible for guaranteeing these rights. Article 50 of the 1992 Constitution established "human rights" for the first time in terms of both definition and content. The Grassroots Democracy regulation (Decree No. 79/2003/ND-CP, Decree No. 29/1998/ND-CP, Resolution No. 45, 1998/NQ-UBTVQH10) in 1998 was considered an important milestone towards achieving democracy and citizens' participation in policy-making $[42,43]$ as it required local governments be more transparent and democratic, consult and monitor, and encourage people to actively take part in social and public management [44]. In 2013, a new constitution elevated the provisions on human rights to the political sphere as evidenced by the use of "human rights and citizens' rights and obligations" instead of "fundamental rights and obligations of citizens" as was the case in all previous constitutions. In addition, the 2013 Constitution recognizes a number of additional rights, including the right to life, the right to culture, and the right to live in a clean environment. The Constitution also asserts: "the rights and the exercise of human rights and citizens' rights may not be abused to infringe upon national interests and others' lawful rights and interests" (Article 15).

In practice, however, the Vietnam Communist Party (VCP) remains dominant, the ultimate source of decisions, limiting political freedom and constraining the autonomy and political participation of Vietnamese citizens $[44,45]$. The official perception of democracy in Vietnam is strongly influenced by Marxist-Leninist ideologies of a centralized democracy whereas Western liberal democracy is depicted in a rather negative way [46]. Thus democracy and human rights remain "sensitive" and the public space remains limited with unclear boundaries [47]. Neither separation of powers nor rule of law, free press, democratic elections, or effective opportunities for people to participate to the national level policy-making exist [42]. Only party members can exercise the right of freedom of expression, although they are still limited by the party's strong emphasis on individual duties for public or national interests [48]. Opposition or different ideas outside the VCP are not permitted, but within its borders, conflicting views on the extent of social and economic freedoms exist [49].

Although the Grassroots Democracy regulation emphasizes the citizen rights of being informed, being consulted, as well as their roles in supervising and deciding, these are often mere slogans and people lack the capability of making their voices heard even at the commune level [50]. Old structures, 
resistance to change by local politicians, mistrust, and officials' lack of knowledge and skills have hampered the transition towards a more open system of governance $[46,48]$, and there has been no significant change on the behavior of governmental staff [50]. This particular political context constitutes a challenging environment for the implementation of FPIC.

\section{Methods}

\subsection{Comparative Analysis of Three Case Studies}

This paper looks at three case studies in Vietnam. Selection was based on the use of FPIC, social and political representation, and the availability and willingness of local authorities, project proponents, and local communities to participate in the study. The case studies also aim to represent different group of project proponents (local CSOs in Thai Nguyen, an intergovernmental organization in Lam Dong, and researcher communities in Nghe An). All three cases studies are pilot projects with a clear objective of experimenting different approaches to draw lessons for REDD+ practitioners and policy makers and are at a very early stage of development. Therefore, we only focus on the first three elements of FPIC and draw lessons learned based on activities implemented so far. A brief description of each of the case study projects is provided below.

\subsubsection{UN-REDD Vietnam Program, Lam Dong Province}

FPIC was piloted in 2010 in 78 villages in the districts of Lam Ha and Di Linh in Lam Dong Province, as part of the UN-REDD Vietnam Program. However, the project practitioners had neither the experience nor clear guidance on how to conduct an FPIC pilot. In theory, the pilot FPIC process involved nine steps: (i) preparation; (ii) consultation with local officials; (iii) recruitment of local facilitators; (iv) training of local facilitators; (v) awareness raising; (vi) village meeting; (vii) recording the decision; (viii) reporting to UN-REDD Vietnam; and (ix) verification and evaluation. In practice, awareness raising and the village meeting were combined, making it an eight-step process. The aim of this exercise was to gain some experience to guide the future national implementation of FPIC.

\subsubsection{Pilot Project to Build Community Readiness for REDD+, Thai Nguyen Province}

This project was launched in the Dai Tu and Vo Nhai districts in Thai Nguyen Province in 2010 and has been managed since 2011 by the Center of Research and Development in Upland Areas (CERDA), a local CSO. The aim of the project was to identify locally based and adapted REDD + approaches that engage communities in implementing FPIC and REDD+ by themselves with the support of sustainable funding. The ethnic minorities are expected to be the initiators for pilot REDD+ activities. The project began by raising awareness about climate change and REDD + among district, commune, and village authorities and villagers. The program included discussion and training on the drivers of deforestation and forest degradation, the role of natural forests, the condition of forests and carbon stocks, requirements under REDD+ such as the Cancun safeguards, and result-based payments. Consultation with district and commune authorities on institutions and aspects of REDD+ implementation, particularly benefit sharing mechanisms and measuring, reporting, and verification (MRV), were followed by consultation with villagers and village heads. Project participants also took part in training 
workshops on democratic rights (as set out in the Grassroots Democracy Ordinance) and alternative livelihood options.

\subsubsection{I-REDD+, Nghe An Province}

The I-REDD+ project (Impacts of Reducing Emissions from Deforestation and Forest Degradation and Enhancing Carbon Stocks) is somewhat different from the other two as it is a research project, with activities in Con Cuong District in Nghe An Province. The aim of I-REDD+ is to ensure that future REDD+ mechanisms are based on the highest level of knowledge about carbon storage in complex landscape mosaics, monitoring technology, impacts on local livelihoods, and governance structures for managing payments and benefit sharing. In one component of the project, a combination of role-playing games and 3D modeling of the village landscape were used to engage village communities in an analysis of the possible impacts of REDD+ on carbon sequestration, livelihood changes, food security, and ecosystem service provision [51]. A large range of participatory methods were tested with local people during two fieldtrips in 2012. The aims of these two fieldtrips were to understand the village history and its influence on local livelihoods, assess the opportunity costs of land-use changes, identify issues related to natural resources management, and rank local priorities for development. As part of the research activities, village communities used simulations to assess the possible impacts of recent land-use changes on their livelihoods and then explore collectively various REDD+ implementation scenarios. These participatory research activities were considered to be a test of how the "informed" component of a future FPIC process may be implemented.

\subsection{Survey Methods}

We conducted six focus group discussions (in two villages in Lam Dong, two villages in Nghe An, and two villages in Thai Nguyen) with a total of 75 participants. In these groups, villagers discussed the strengths and weaknesses of the content, process, and dissemination methods proposed during each project and looked at ways to deal with the pitfalls, to better capture local preferences and choices. In addition we conducted open-ended interviews with central government staff (four), provincial government staff and with non-governmental organizations (NGOs) (10 informants in Thai Nguyen, six in Nghe An, and six in Lam Dong). Household interviews were also conducted with 42 randomly selected villagers who had participated in project activities and who were available and willing to participate in the study. The aim of these interviews was to learn how stakeholders evaluated approaches of each project to informing villagers about REDD+, their perceptions and understanding of REDD+, and the pros and cons of the method used for implementing FPIC.

\section{Results and Discussion}

\subsection{FPIC as a Rights-Based Approach Embedded in the National Legal Framework}

Although the government has developed supportive democracy policies that clearly indicate the rights of citizens and communities, there is a reluctance to give more rights and power to local communities. Vietnam is one of the first countries to pilot FPIC, as part of the UN-REDD Program [25], but FPIC is neither mentioned in the National REDD+ Program (Decision 799/2012 approved by the Prime 
Minister), nor has Vietnam developed specific guidelines or manuals. The absence of FPIC from the legal framework leaves it open for government staff as well as project proponents in the three cases to make their own interpretations of FPIC. Nevertheless, the government control remains firm. Though representatives of the central government asserted that citizens can exert their right to reject REDD+, the government can override their decision and impose a program if it is seen as crucial for national development. This perception is rooted in the strong political view that "free consent" must remain within legal and constitutional boundaries. Authorities of all government agencies interviewed also expressed their concerns about allowing people to exercise such rights, as they were not confident that local people had enough information on or understanding of REDD + and similar mechanisms to be able to exercise their rights effectively.

Lacking clear guidance on how to implement FPIC, project proponents in the three cases interpreted and implemented FPIC in different ways (Table 1) based on their project objectives and expected outcomes, leading to different understanding of FPIC by local authorities and local people (Table 2). The local CSO in Thai Nguyen was the only one explicitly linking FPIC to the grassroots democracy regulations and Vietnam's constitution. An interviewee of this local CSO asserted that "it is very challenging to implement FPIC in Vietnam because the concepts of human rights, citizen rights, and democracy are seen as politically sensitive and CSO cannot operate freely like in other countries. What we do will have to comply with or be based on national regulations. We read the principles of FPIC and see the only way to make FPIC work is to link to grassroots democracy regulations [if] local authorities are willing to uptake this idea." As a result, while central government representatives and authorities interviewed in Lam Dong and Nghe An were quite skeptical about FPIC implementation in their province, the Thai Nguyen case received strong political support and interest from both the central government and Thai Nguyen local authorities. A government representative in Thai Nguyen stated that "When we first heard about FPIC, we were very concerned as indigenous human rights and citizen rights are indeed very sensitive. However, when the project proponent explained that this is nothing new and that it complies with grassroots democracy regulations and the Vietnam constitution, we were much more confident and supportive of the project." A central government interviewee also stated that "although there is no clear guidance and common understanding on FPIC in Vietnam, the case of Thai Nguyen shows how applying international requirement to national contexts facilitates government commitment. Other approaches adopted in other REDD+ project are often seen as exogenous models unrelated to national regulations. Conversely, project proponents had more problems introducing and getting acceptance of FPIC among local authorities." Using the permitted political space to implement FPIC and making use of the actual citizen's rights help local government authorities to accept, understand, and therefore support the implementation of FPIC as part of their daily work and assignments.

As was shown in Thai Nguyen and also suggested by Doyle [30], FPIC can easily include information on national legislation, including the degree of recognition of the right to FPIC and other self-determination rights. Indeed, to ensure that FPIC is well- placed and well implemented at all scales, legally binding obligations and clear domestic legislation modeled after international norms are required [13]. In Thai Nguyen, the project not only informed people about the content of the REDD + project but also provided training on grassroots democracy, legal rights (as set out in Vietnam's Law on Complaints and Denunciations, and Law on Cooperatives), and the rights and responsibilities of village leaders (Table 2). By contrast, in the case of the UN-REDD Program the FPIC team leaders were apparently familiar with 
national guidelines and documents on grassroots democracy, but there was no evidence that these guidelines had been incorporated into the FPIC process [52].

Table 1. Implementation of FPIC in three projects.

\begin{tabular}{|c|c|c|c|}
\hline FPIC activities & Thai Nguyen & Nghe An & Lam Dong \\
\hline $\begin{array}{l}\text { Venue of meeting and } \\
\text { presence of powerful actors }\end{array}$ & $\begin{array}{l}\text { Commune and cooperative } \\
\text { meeting: commune's hall. } \\
\text { Forest protection unit: } \\
\text { group leader's house. } \\
\text { Powerful actors are } \\
\text { present. }\end{array}$ & $\begin{array}{l}\text { Houses of heads of } \\
\text { villages or village hall. } \\
\text { Powerful actors are absent. }\end{array}$ & $\begin{array}{l}\text { Village hall or village } \\
\text { common meeting place. } \\
\text { Powerful actors are absent. }\end{array}$ \\
\hline $\begin{array}{l}\text { People have been informed of } \\
\text { their rights, and are allowed to } \\
\text { say no to proposed } \\
\text { project activities. }\end{array}$ & Yes & Yes & Yes \\
\hline $\begin{array}{l}\text { People are given sufficient } \\
\text { time to consider the } \\
\text { information provided. }\end{array}$ & 2 years & 3 days/village & $2 \mathrm{~h} /$ village \\
\hline $\begin{array}{l}\text { External facilitators are able to } \\
\text { work in a competent manner } \\
\text { and be reasonably neutral } \\
\text { and independent. }\end{array}$ & $\begin{array}{l}\text { Project facilitators are } \\
\text { respected and favored by } \\
\text { local people. } \\
\text { Half of local facilitators do } \\
\text { not have the skills required } \\
\text { and are not trusted by } \\
\text { local people. }\end{array}$ & $\begin{array}{l}\text { Facilitators are trusted and } \\
\text { respected by local } \\
\text { communities but both } \\
\text { parties face } \\
\text { language barriers. }\end{array}$ & $\begin{array}{l}\text { Facilitators can speak the } \\
\text { local language but were } \\
\text { unable to convey the key } \\
\text { message to local people. }\end{array}$ \\
\hline
\end{tabular}

Table 2. Stakeholders' perceptions on FPIC.

\begin{tabular}{|c|c|c|c|}
\hline Actors involved in FPIC & Thai Nguyen & Nghe An & Lam Dong \\
\hline District authorities & $\begin{array}{l}\text { A consultation and } \\
\text { decision-making process } \\
\text { toward livelihood } \\
\text { improvement and better } \\
\text { forest protection activities } \\
\text { and REDD+. }\end{array}$ & $\begin{array}{l}\text { A normal project on forest } \\
\text { protection and social and } \\
\text { economic development. } \\
\text { Support FPIC to be carried } \\
\text { out in the area but requires } \\
\text { projects to report detailed } \\
\text { activities/outcomes after } \\
\text { each trip and are cautious } \\
\text { about the potential political } \\
\text { use of FPIC. }\end{array}$ & $\begin{array}{l}\text { donor's requirements; not } \\
\text { very useful as it is not } \\
\text { tailored to the actual needs } \\
\text { and level of education of } \\
\text { local people }\end{array}$ \\
\hline $\begin{array}{l}\text { Commune authorities } \\
\text { Village management } \\
\text { boards }\end{array}$ & $\begin{array}{l}\text { A process to comply with } \\
\text { the Grassroots Democracy } \\
\text { Regulation and ensure } \\
\text { citizen rights }\end{array}$ & $\begin{array}{l}\text { invented by the project } \\
\text { simply project activities }\end{array}$ & donor's requirements \\
\hline Local people & $\begin{array}{l}\text { A means to enhance } \\
\text { understanding of local } \\
\text { people about their rights } \\
\text { and collective actions }\end{array}$ & simply project activities & donor's requirement \\
\hline
\end{tabular}


Yet, even with the political support and acceptance from government staff such as in the case of the Thai Nguyen project, operating FPIC remains challenging. Government control remains strong and political space for participation is limited. In Vietnam, no project activity is allowed without the presence of authorities. Freely given consent "with no coercion, manipulation, or intimidation" through a community-driven process remains elusive and project proponents are limited in experimenting with different approaches when introducing REDD+ to the villagers.

The selection of facilitators is also politically driven. In Thai Nguyen, the project proponents interviewed said they preferred to select villagers who already had communication skills, as they believed that these independent facilitators would be free of any political interests. However, the commune authority obliged the project proponents to nominate the local first secretary of the Communist Party as facilitator as a condition for the project to be approved. According to all villagers interviewed in Thai Nguyen, these facilitators, as party members, were unable to create an environment in which villagers felt comfortable enough to discuss their ideas freely. All villagers interviewed also claimed that the village leaders (nominated by the state) in all three sites often attempted to control the participatory process and to prevent villagers' discussions of the facilitators' selection process. In all three cases studies, project implementers and local authority representatives stated that the absence of local government officials allowed a more open environment in which local people can speak out. However, when government officers are not involved, they are unlikely to support (or sometimes even approve) consultations at village level.

Baker [18] suggested that the appropriate way to achieve FPIC is to first agree on key principles of an overall framework and then consider context-specific aspects once designs are further advanced and locations are determined. As stated earlier, the government of Vietnam has indirectly committed to FPIC, partly because the government signed up for international and regional human rights treaties, and partly because FPIC is in line with the existing Vietnam Constitution and Grassroots democracy regulation. As the three projects have demonstrated and as the Vietnam Constitution and Grassroots democracy regulation requires, stakeholders entitled to FPIC will have to include both indigenous people and wider communities. The inclusion of FPIC in the national REDD + program, together with guidance on operational principles, could serve as an obvious legal platform for FPIC implementation. Better understanding of FPIC principles on the part of central and provincial governments would also help to embed those principles in practice.

\subsection{FPIC as a Learning Process and Empowerment Tool}

As indicated above, in each of the three sites, different ways of implementation were used and different information was conveyed, which resulted in different perceptions. On the other hand, in all cases, the "Informing" stage was done through indoor meetings (most often at the house of a village leader or the community hall) (Table 3). Interviewees in Lam Dong and Nghe An pointed out that holding the activities outdoors would not only improve explanations about the linkages between forests, climate change mitigation, and their livelihoods, but also reduce the stress of being intensively put in study mode. 
Table 3. How and where information was provided at the three sites.

\begin{tabular}{llll}
\hline $\begin{array}{c}\text { FPIC } \\
\text { information } \\
\text { sharing }\end{array}$ & \multicolumn{1}{c}{ Thai Nguyen } & \multicolumn{1}{c}{ Nghe An } & \multicolumn{1}{c}{ Lam Dong } \\
\hline & $\begin{array}{l}\text { Indoor meetings; Face to } \\
\text { face between group leaders } \\
\text { and cooperative members; }\end{array}$ & $\begin{array}{l}\text { Indoor meetings; } \\
\text { Presentation, role-play } \\
\text { gresentations, video, } \\
\text { diagrams, handouts } \\
\text { in Vietnamese. }\end{array}$ & $\begin{array}{l}\text { Indoor meetings; } \\
\text { verbal presentation, } \\
\text { visualization and poster; } \\
\text { handouts in Vietnamese } \\
\text { and the local language. }\end{array}$ \\
\hline $\begin{array}{l}\text { Who } \\
\text { participated? }\end{array}$ & All villagers & All villagers & $\begin{array}{l}\text { Representatives selected } \\
\text { through a survey } \\
\text { on households }\end{array}$ \\
\hline
\end{tabular}

With meetings held indoors, information was conveyed mostly through conventional approaches like Powerpoint presentations and handouts. These were not very effective in creating open and free discussions. Only in Nghe An, project proponents introduced role-playing for land-use simulations, which helped build trust between villagers and facilitators and minimize the influence of powerful actors. As implied, communicating REDD + requires a mix of methods and strategies, from verbal to visual and from normative to affective. However, facilitators and communicators can only be sure that their messages will be understood if they, in turn, understand their audiences, including their values, fears, and hopes, and the context in which the communication is taking place [53]. The learning process should thus be a two-way process whereby all parties participate in the learning.

The three cases studied show that a knowledgeable and skilled facilitator was a determining factor for people's participation in project activities. However, different types of facilitators are perceived differently. In Thai Nguyen and Lam Dong, there were two groups of facilitators: (i) the core group, including REDD+ experts, who came from the project; and (ii) local facilitators who were selected and trained by the core group. Both of these groups carried out consultations in the same communities. All interviewees said that they preferred consultations with the external experts over consultations with local facilitators, for two main reasons. First, trained local facilitators can deliver basic information on the topic but cannot engage in two-way communication because they do not have sufficient knowledge to respond to questions. Second, villagers felt that local facilitators are not neutral, even if they speak the local language. The perception is that, in a community made up of three or four ethnic groups, local facilitators might be biased toward a certain group and cannot be neutral when facilitating the discussion. Similarly, in Nghe An, villagers interviewed reported that they had enjoyed having external expert facilitators with no association with local issues or organizations.

Learning also requires ownership of the local people in the process. However, according to the villagers interviewed in all three provinces, local people had limited influence on how and about what they were to be informed. Project proponents made decisions about the training content and methods without consulting community members about their needs or preferences. Although this is attributable, at least in part, to the limited time and resources available for designing the training, it also implies that the project proponents did not have sufficient information to be able to effectively tailor their training 
activities to the interests and capacity of the trainees. The process should not only be about informing but also about consulting, discussing, and learning.

Given the limitations of time and financial resources that most projects face, trade-offs must be made between the need to include all villagers in the process and the difficulties of training large disparate groups. Inviting a smaller group to take part in the learning process may be more efficient if participants are selected carefully and appropriate mechanisms for passing on the information are in place. Indigenous peoples should be able to participate through their own freely chosen representatives and customary institutions. The inclusion of a gender perspective and the participation of indigenous women are essential, as well as the participation of children and youth as appropriate.

Learning for empowerment, however, is not only a matter of providing information but needs to be accompanied by efforts to help communities understand the issues. It requires an inclusive and equitable dialogue, allowing all stakeholders to develop appropriate solutions in an atmosphere of mutual respect, and thus requires ample time and an effective system for communicating among stakeholders. Preparations by I-REDD+ included several field trips before the focus group discussions, and the CERDA project included a thorough two-year baseline study, which enabled these two projects to tailor their approaches to local interests. By contrast, the project in Lam Dong showed that more conventional approaches to communicating REDD+, with a relatively narrow focus on scientific findings, synthesis reports, and descriptions of extreme weather events, tend to remain rather abstract for local people. Moreover, local villagers interviewed in Lam Dong also claim that $2 \mathrm{~h}$ of discussion (see Table 1) is not enough for local communities to understand REDD+.

As a learning process, targeted stakeholders including both local government and local people must be provided with accurate and comprehensive information about REDD + . The information provided also needs to address the potential positive and negative impacts of REDD+. Villagers in Lam Dong and Thai Nguyen claimed they were only told about the positive impacts of REDD+. Only people in Nghe An were informed of the potentially negative impacts. In Lam Dong in particular, people were not informed about the risks associated with taking part in the program or of the costs they might incur [52]. As a result, it has raised unrealistic expectations that the new projects would provide them with alternative livelihood options, better forest protection, and development opportunities. Although these perceptions fueled people's interest in taking part, it is essential to avoid creating unrealistic expectations among local people.

Feedback was also minimal. Interviewees in the three sites highlighted that although much information was provided and agreement was reached on how REDD+ would be implemented, in none of the study sites were local people given the minutes or any other records of the meetings. In Lam Dong the minutes were read back to attendees at the end of the village meeting, but in Nghe An, minutes were taken for research purposes but not shared with local people (as the project was not actually implementing REDD+). In Lam Dong, the meeting proceedings were recorded but not in great detail. Yet, both local authorities and villagers interviewed in the three sites expressed their strong interest to be provided such information for future use.

Policy makers often assume ordinary people lack full knowledge and understanding of climate change and therefore are poor decision makers in need of expert support [54,55]. Nerlich et al. [53] criticize this tendency to differentiate between expert and non-expert, claiming that communication should be grounded in dialogue and contextual understanding. Therefore, communication should be seen as part 
of collective action [56] and social learning [57] and needs to be based on a better understanding by facilitators not only of the target audience but also of how to engage them affectively, connecting the messages to cultural values and beliefs $[31,54]$. Furthermore, as the content and availability of accurate and clear information on REDD + are still evolving, there are inherent difficulties in informing communities of details about which neither local people nor most project staff have a firm understanding [19,52,58]. FPIC should therefore be understood as a long-term learning process [19] and the political, economic, and social context needs to be carefully analyzed and taken into account in the FPIC design process [13].

As highlighted by the case studies, FPIC, if designed and implemented well, can be an effective learning tool to empower local communities and enhance their participation in development and design of REDD+ [59-62] and thereby address some of the underlying social drivers of deforestation [63]. The concept of FPIC built on the national legal framework might not be new to local government and local people, but certainly the practice has not been exercised widely. Thus, it should be seen as a learning process for both local people and local authorities. FPIC regimes must therefore be set up in such a way that they encourage productive and informed engagement of local people [28]. Given the great disparities in power and resources between the actors involved, FPIC might run the risk of constantly reinforcing and legitimizing the dominant actors. The details of procedural norms (e.g., who will participate, how long the consultation will last, what type of compensation should be made) therefore need to be considered and designed carefully [29]. The format in which information is conveyed should take into account social, institutional, and cultural barriers [25,31,58]. Communication and consultation processes must be culturally appropriate, with information provided in the appropriate language.

\section{Conclusions}

FPIC has evolved gradually, and is the result of both hard and soft legal norms at international and national levels. Yet, there is a gap between international norms and national practice, due to specific political and economic conditions in each country. How FPIC is translated on the ground depends on political views, government interests, and the local governments' understanding of FPIC. In line with Savaresi [38], this paper has shown that integrating REDD+ with human rights obligations would avoid duplicating efforts and exploit the consensus that already underpins existing human rights instruments. As such, it follows that the more rights-based approaches to conservation efforts are successful where secure rights to resources underpin community engagement [64]. Our findings show that framing FPIC within the human rights and grassroots regulations will provide the added benefit of institutional support to better implement and enforce FPIC.

Our paper also shows that political regimes (e.g., Vietnam's command and control system) may undermine the implementation of FPIC on the ground if interpretations of the elements "free", "prior", and "informed consent" do not adhere to the intentions of FPIC. The unwillingness of the political elite to transfer decision-making power from state to non-state actors has strong implications for access to and control over resources and the understanding of what FPIC means. Better information to local authorities about REDD+ and the role of FPIC as embedded in national policies and context can help to 
move FPIC and REDD+ forward, but this also depends on the willingness of governments to provide political space for other actors.

FPIC should also be treated as a learning process; the information provided should be useful for participants and the ways information is provided should be accommodated with adequate venues and accountable and independent facilitators. Sufficient timing and budget is also required for careful implementation. Consultations take place within a highly dynamic and complex political and socioeconomic context. As seen in these case studies from Vietnam, no single approach will fit all situations. Informing local communities about REDD+ is a complex and challenging task because of the nature and impacts of REDD+ itself, the range of knowledge needed to respond to it, and the ability of facilitators to ensure that learning processes are both dynamic and accountable. Given the diversity of local socioeconomic settings, FPIC guidelines need to be flexible enough to be adaptable to national and local contexts, where legislation must acknowledge that FPIC is an adaptive learning process focused on enhancing stakeholders' engagement in REDD+.

\section{Acknowledgments}

This study was supported by I-REDD+ (Impacts of Reducing Emissions from Deforestation and Forest Degradation and Enhancing Carbon Stocks), which is funded by the European Community's Seventh Framework Program (www.i-redd.eu), and the Global Comparative Study on REDD+, which is coordinated by the Center for International Forestry Research and funded by AusAID, Norad and UKaid.

\section{Author Contributions}

Pham Thu Thuy, Le Ngoc Dung, Nguyen Dinh Tien and Vu Thi Hien collected primary data and undertook the analysis of the evidence data. All authors contributed to writing the manuscript.

\section{Conflicts of Interest}

The authors declare no conflict of interest.

\section{References}

1. Caney, S. Climate change, human rights and moral thresholds. In Human rights and Climate Change; Humphreys, S., Ed.; Cambridge University Press: Cambridge, UK, 2010; pp. 69-91.

2. Roth-Arriaza, N. "First, do no harm": Human rights and efforts to combat climate change. Ga. J. Int. Comp. Law 2010, 38, 593-612.

3. Mustalahti, I.; Rakotonarivo, O.S. REDD+ and empowered deliberative democracy: Learning from Tanzania. World Dev. 2010, 59, 199-211.

4. Phelps, J.; Webb, L.E.; Agrawal, A. Does REDD+ threaten to recentralize forest governance? Science 2010, 328, 312-313. 
5. Jagger, P.; Lawlor, K.; Brockhaus, M.; Gebara, M.F.; Sonwa, D.; Resosudarmo, I.A.P. REDD+ safeguards in national policy discourse and pilot projects. In Analysing REDD+: Challenges and Choices; Angelsen, A., Brockhaus, M., Sunderlin, W.D., Verchot, L.V., Eds.; Center for International Forestry Research: Bogor, Indonesia, 2012.

6. Ribot, J.; Larson, A.M. Reducing REDD risks: Affirmative policy on an uneven playing field. Int. J. Commons. 2012, 6, 233-254.

7. McDermott, C.L.; Coad, L.; Helfgott, A.; Schroeder, H. Operationalizing social safeguards in REDD+: Actors, interests and ideas. Environ. Sci. Policy 2012, 21, 63-72.

8. Humphreys, S. Introduction: Human rights and climate change. In Human Rights and Climate Change; Humphreys, S., Ed.; Cambridge University Press: Cambridge, UK, 2010; pp. 1-134.

9. Angelsen, A.; Brockhaus, M.; Sunderlin, W.D.; Verchot, L.V. Analysing REDD+: Challenges and Choices; Center for International Forestry Research: Bogor, Indonesia, 2012.

10. Lyster, R. REDD+, transparency, participation and resource rights: The role of law. Environ. Sci. Policy 2011, 14, 118-126.

11. Mertz, O.; Müller, D.; Sikor, T.; Hett, C.; Heinimann, A.; Castella, J.C.; Lestrelin, G.; Ryan, C.M.; Reay, D.S.; Schmidt-Vogt, D.; et al. The forgotten D: Challenges of addressing forest degradation in complex mosaic landscapes under REDD+. Geogr. Tidsskr. 2012, 112, 63-76.

12. UN Secretary General. Road Map towards the Implementation of the United Nations Millenium Declaration; UN Doc. A/56/326; UN Secretary General: New York, NY, USA, 2001.

13. Ward, T. The Right to Free, Prior, and Informed Consent: Indigenous Peoples' Participation Rights within International Law. Available online: http://scholarlycommons.law.northwestern.edu/njihr/ vol10/iss2/2 (accessed on 31 May 2015).

14. Own, R.J.; Kemp, D. "Free prior and informed consent", social complexity and the mining industry: Establishing a knowledge base. Resour. Policy 2014, 41, 91-100.

15. UN-REDD. Guidelines on Free, Prior and Informed Consent; UN-REDD Programme: Geneva, Switzerland, 2013.

16. United Nations Permanent Forum on Indigenous Issues (UNPFII). Report on the Seventh Session; UN Doc. E/2008/43.E/C.19/2008/13; UNPFII: New York, NY, USA, 2005.

17. RECOFTC (The Center for People and Forests). Free, Prior, and Informed Consent in REDD+. 2012. Available online: http://www.recoftc.org/site/resources/FPIC-in-REDD-/ (accessed on 31 May 2014).

18. Baker, S. Why the IFC's free, prior, and informed consent policy does not matter (yet) to indigenous communities affected by development projects. Wis. Int. Law J. 2012, 3, 668-705.

19. Anderson, P. Free, Prior, and Informed Consent in REDD+: Principles and Approaches for Policy and Project Management; The Center for People and Forests: Bangkok, Thailand, 2011.

20. Esteves, M.A.; Franks, D.; Vanclay, F. Social impact assessment: The state of the art. IAPA 2012, 30, 34-42.

21. Colchester, M.; Ferrari, M.F. Making FPIC Work: Challenges and Prospects for Indigenous Peoples; FPIC Working Papers; Forest Peoples Programme: Moreton-in-Marsh, UK, 2007.

22. Hanna, P.; Vanclay, F. Human rights, indigenous peoples and the concept of free, prior and informed consent. IAPA 2013, 31, 146-157. 
23. Inman, D.; Smis, S.; Cambou, D. We will remain idle no more: The shortcomings of Canada's "Duty to Consult" Indigenous Peoples. GoJIL 2013, 1, 251-285.

24. Motoc, A. Standard-Setting: Legal Commentary on the Concept of Free, Prior and Informed Consent. In Proceedings of the Twenty-Third Session of the United Nations Working Group on Indigenous Populations, Geneva, Switzerland, 18-22 July 2005.

25. UN-REDD. FPIC for REDD+ in the Asia Pacific Region: Lessons Learned, Challenges and Recommendations; UN-REDD Programme: Geneva, Switzerland, 2012.

26. World Bank. OP 4.10-Indigenous Peoples. 2005. Available online: http://web.worldbank.org/ WBSITE/EXTERNAL/PROJECTS/EXTPOLICIES/EXTOPMANUAL/0,,contentMDK:2055365 3 menuPK:4564185 pagePK:64709096 piPK:64709108 theSitePK:502184,00.html (accessed on 31 May 2015).

27. Mahanty, S.; McDermott, C.L. How does "Free, Prior and Informed Consent" (FPIC) impact social equity? Lessons from mining and forestry and their implications for REDD+. Land Use Policy 2013, 31, 406-416.

28. Szablowski, D. Operationalizing free, prior, and informed consent in the extractive industry sector? Examining the challenges of a negotiated model of justice. Rev. Can. Études Dév. 2010, 30, 111-130.

29. Rodríguez-Garavito, R.C. Ethnicity.gov: Global governance, indigenous peoples, and the right to prior consultation in social minefields. Ind. J. Glob. Leg. Stud. 2011, 18, 263-305.

30. Doyle, G. Indigenous peoples and the Millennium Development Goals: "Sacrificial lambs" or equal beneficiaries? Int. J. Hum. Rights 2009, 13, 44-47.

31. Thompson, M.C.; Baruah, M.; Carr, E.R. Seeing REDD+ as a project of environmental governance. Environ. Sci. Policy 2011, 14, 100-110.

32. Forrester, J.M.; Hicks, K.; Kuylenstierna, J.C.I.; Simon, J.; Snell, C.J.; Chadwick, M.; Schwela, D.H.; Emberson, L.D. Governance of Air Quality and Stakeholder Engagement. In Governing the Air: Science-Policy-Citizens Dynamics in International Environmental Governance; Lidskog, R., Sudqvist, G., Eds.; MIT Press: Cambridge, MA, USA, 2011.

33. Nijar, G.S. Traditional Knowledge Systems, International Law and National Challenges: Marginalization or Emancipation? Eur. J. Int. Law 2013, 24, 1205-1221.

34. Engle, L.K. On Fragile Architecture: The UN Declaration on the Rights of Indigenous Peoples in the Context of Human Rights [Symposium: The Human Dimension of International Cultural Heritage Law]. Eur. J. Int. Law 2011, 22, 141-163.

35. Barelli, M. Shaping Indigenous Self-Determination: Promising or Unsatisfactory Solutions? Int. Community Law Rev. 2011, 13, 413-436.

36. Cowan, A. UNDRIP and the intervention: Indigenous self-determination, participation, and racial discrimination in the northern territory of Australia. Pac. Rim Law Policy J. 2013, 22, 247-310.

37. ClientEarth; World Resources Institute. Lessons from International and Regional Instruments; A Submission to the Subsidiary Body for Scientific and Technical Advice (SBSTA); ClientEarth: London, UK; World Resources Institute: Washington, DC, USA, 2011.

38. Savaresi, A. REDD+ and Human Rights: Addressing Synergies between International Regimes. Ecol. Soc. 2013, 18, doi:10.5751/ES-05549-180305. 
39. UN-REDD Programme and Vietnam Administration of Forestry (VNFOREST). Guidelines on Application of FPIC in REDD + Preparation and Implementation in Vietnam; UN-REDD Program: Hanoi, Vietnam, 2014.

40. Nhan Dan Newspaper. Human Rights for the Development of Ethnic Minority Groups. Nhan Dan Newspaper: 2013. Available online: http://www.nhandan.com.vn/chinhtri/binh-luan-phephan/item/21890602-nhan-quyen-vi-su-phat-trien-cua-cac-dan-toc-thieu-so.html (accessed on 31 May 2015).

41. International Work Group for Indigenous Affairs (IWGIA). The Indigenous World: Vietnam. 2012. Available online: http://www.iwgia.org/images/stories/sections/regions/asia/documents/IW2012/ vietnam_iw_2012.pdf (accessed on 31 May 2015).

42. Frehner, W. Hintergrundinformationen zu Vietnam (Background Information in Vietnam). 2007. Available online: http://www.kas.de/proj/home/home/72/1/index.html (accessed on 31 May 2015).

43. Ha, K.N. Vietnam Revisited —Demokratisierung, Nationale Identität und Adoleszente Arbeitsmigration (Vietnam Revisited-Democratization, National Identity and Adolescent Labor Migration); Wissenschaftlicher Verlag Berlin: Berlin, Germany, 2005.

44. Nguyen, H.T.N. The Roles of Civil Society Organizations in Enhancing Grassroots Democracy in Vietnam; International Institute of Social Studies: The Hague, The Netherlands, 2012.

45. Pham, T.T.; DiGregorio, M.; Carmenta, R.; Brockhaus, M.; Le, N.D. The REDD+ policy arena in Vietnam: Participation of policy actors. Ecol. Soc. 2014, 19, doi:10.5751/ES-06389-190222.

46. Aschhoff, N. What Role Can Local NGOs Play to Support Grassroots Democracy in Vietnam? The Example of the Vietnamese NGO CRP. 2008. Available online: http://www.kas.de/wf/doc/ kas_14689-544-2-30.pdf(accessed on 31 May 2015).

47. Norlund, I.; Dang, N.B.; Bach, T.S.; Chu, D.; Dang, N.Q.; Do, B.D.; Nguyen, M.C.; Tang, T.C.; Vu, C.M. The Emerging Civil Society: An Initial Assessment of Civil Society in Vietnam; CIVICUS Civil Society Index Shortened Assessment Tool CSI-SAT Vietnam; Civicus Civil Society Index Shorterned Assessment; Vietnam Institute of Development Studies; UNDP Vietnam; SNV Vietnam; CIVICUS Civil Society Index; Vietnam Institute of Development Studies: Hanoi, Vietnam, 2006.

48. Duong, M.N. Grassroots Democracy in Vietnamese Communes; Research Paper; The Centre for Democratic Institutions; Research School of Social Sciences; Australian National University: Canberra, Australia, 2004.

49. Wischermann, J. Ein Land Zwischen Sozialismus und Kapitalismus-Wohin Steuert Vietnam (A Country between Socialism and Capitalism-Where Controls Vietnam?); Deutsch-Vietnamesische Gesellschaft: Berlin, Germany, 1994.

50. Nguyen, H.H.; Hoang, M.H. Improvenments of grassroot democracy implementation to ensure human rights in Vietnam. Soc. Scie. Inf. Rev. 2012, 6, 35-43.

51. Bourgoin, J.; Castella, J.C.; Hett, C.; Lestrelin, G.; Heinimann, A. Engaging local communities in low emissions land use planning: A case study in Laos. Ecol. Soc. 2013, 18, doi:10.5751/ ES-05362-180209.

52. Nguyen, Q.T.; Luong, T.T.; Nguyen, T.H.V.; K'Tip. Evaluation and Verification of the Free, Prior and Informed Consent Process under the UN-REDD Programme in Lam Dong Province, Vietnam; The Center for People and Forests: Bangkok, Thailand, 2010. 
53. Nerlich, B.N.; Koteyko, N.; Brown, B. Theory and language of climate change communication. WIRES Clim. Chang. 2010, 1, 97-110.

54. Shackley, S.; Wynne, B. Global warming potentials: Ambiguity or precision as an aid to policy? Clim. Res. 1997, 8, 89-106.

55. Thaler, R.; Sunsteen, C. Nudge: Improving Decisions about Health, Wealth and Happiness; Yale University Press: New Haven, CN, USA, 2008.

56. Keen, M.; Brown, V.A.; Dyball, R. Social Learning in Environmental Management: Towards a Sustainable Future; Earthscan: London, UK, 2005.

57. Reed, M.S.; Evely, A.C.; Cundill, G.; Fazey, I.; Glass, J.; Laing, A.; Stringer, L.C. What is social learning? Ecol. Soc. 2010, 15, 1.

58. Boyle, T. Application of free prior informed consent in the UN-REDD Programme: Experiences from Vietnam. In Proceedings of the UN-REDD FPIC Workshop, Arusha, Tanzania, 24-27 January 2011.

59. Gebara, M.F. Importance of local participation in achieving equity in benefit-sharing mechanisms for REDD+: A case study from the Juma Sustainable Development Reserve. IJC 2013, 7, 473-497.

60. Griffiths, T. Seeing “REDD”? Forests, Climate Change Mitigation and the Rights of Indigenous Peoples and Local Communities; Forest Peoples Programme: Moreton-in-Marsh, UK, 2008.

61. Peskett, L.; Huberman, D.; Bowen-Jones, E.; Edwards, G.; Brown, J. Making REDD Work for the Poor. Prepared on Behalf of the Poverty Environment Partnership; Overseas Development Institute: London, UK, 2008.

62. Lawlor, K.; Madeira, E.M.; Blockhus, J.; Ganz, D.J. Community Participation and Benefits in REDD+: A Review of Initial Outcomes and Lessons. Forests 2013, 4, 296-318.

63. Hajek, F.; Scriven, J.; Castro, A.; Ventresca, M.J. Regime Building for REDD+: Evidence on Anatomy and Proximate Outcomes from a Cluster of Local Initiatives in South-Eastern Peru. Environ. Sci. Policy 2011, 14, 201-215.

64. Campese, J.; Sunderland, T.; Greiber, T.; Oviedo, G. Rights-Based Approaches: Exploring Issues and Opportunities for Conservation; Center for International Forestry Research (CIFOR) and International Union for Conservation of Nature (IUCN): Bogor, Indonesia, 2009.

(C) 2015 by the authors; licensee MDPI, Basel, Switzerland. This article is an open access article distributed under the terms and conditions of the Creative Commons Attribution license (http://creativecommons.org/licenses/by/4.0/). 